\title{
Novel Dimethyltyrosine-Tetrahydroisoquinoline Peptidomimetics with Aromatic Tetrahydroisoquinoline Substitutions Show In Vitro Kappa and Mu Opioid Receptor Agonism
}

\author{
Deanna Montgomery ${ }^{\dagger}$, Jessica P. Anand ${ }^{\ddagger}, \S$, Nicholas W. Griggs ${ }^{\ddagger}$, Thomas J. Fernandez ${ }^{\ddagger}$, \\ Joshua G. Hartman ${ }^{\ddagger}$, Ashley A. Sánchez-Santiago ${ }^{\ddagger}$, Irina D. Pogozheva ${ }^{\dagger}$, John R. \\ Traynor ${ }^{\ddagger}$, , Henry I. Mosberg ${ }^{\dagger, \S},{ }^{*}$ \\ † Department of Medicinal Chemistry, College of Pharmacy, University of Michigan, Ann Arbor, \\ Michigan 48109 United States \\ ‡ Department of Pharmacology, Medical School, University of Michigan, Ann Arbor, Michigan \\ 48109 United States \\ $\S$ Edward F. Domino Research Center, Medical School, University of Michigan, Ann Arbor, \\ Michigan 48109 United States
}

\section{Abstract}

The dimethyltyrosine-tetrahydroisoquinoline (Dmt-Tiq) scaffold was originally developed in the production of selective delta opioid receptor (DOR) antagonists. Installation of a 7-benzyl pendant on the tetrahydroisoquinoline core of this classic opioid scaffold introduced kappa opioid receptor (KOR) agonism. Further modification of this pendant resulted in retention of KOR agonism and the addition of mu opioid receptor (MOR) partial agonism, a bifunctional profile with potential to be used in the treatment of cocaine addiction.

\section{Graphical Abstract}<smiles>Cc1cc(O)cc(C)c1C[C@H](N)C(=O)N1Cc2ccccc2C[C@H]1C(=O)O</smiles>

DOR antagonist

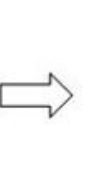

$\mathrm{R}$

\section{KOR agonist/} MOR agonist

\section{Keywords}

opioids; multifunctional ligands; peptidomimetics; cocaine addiction; synthesis; dimethyltyrosinetetrahydroisoquinoline

*Corresponding Author Information: Phone: 734-764-8117, Fax: 734-763-5595, him@umich.edu.

Author Contributions

DM designed and synthesized novel compounds and wrote the manuscript under the direction of HIM. JPA, NWG, JGH, and TJF collected in vitro data under the direction of JRT. IDP performed modeling studies.

Supporting Information

Detailed experimental methods and characterization data for compounds $\mathbf{4 a - 4 d , ~ 1 0 a - 1 0 i , ~ a n d ~ r e l a t e d ~ i n t e r m e d i a t e s ~}$ 


\section{Introduction}

The opioid receptors and their associated endogenous ligands were discovered as a result of early medicinal and recreational use of opium. These receptors are ubiquitously expressed throughout the brain and peripheral and central nervous systems and are known to be involved in a variety of biological and physiological processes. Among other functions, the three major types of opioid receptors - kappa (KOR), mu (MOR), and delta (DOR) modulate pain, ${ }^{1-3}$ mood, ${ }^{4-6}$ reward ${ }^{7-9}$ stress, ${ }^{4,10}$ respiration, ${ }^{11,12}$ and gastrointestinal function. ${ }^{12,13}$ Endogenous and exogenous opioids elicit effects on many of these activities, giving opioids great potential as therapeutic agents for a wide assortment of indications. As a result, the opioid system has been intensely studied for several decades, and many semisynthetic and synthetic opioid ligands have been developed as therapeutics and chemical tools. The endogenous opioid ligands, discovered in the 1970s, are peptides, and their structure-activity relationships (SAR) have been well-studied through the synthesis of numerous peptide and peptidomimetic analogues. ${ }^{1,14-18}$ As a result of this work, many novel opioid ligands have been developed. Early progress in the discovery of synthetic opioids focused on the development of selective ligands for each receptor type, following the traditional drug discovery convention of using selectivity to minimize unwanted off-target side effects and creating tools to further elucidate the functions of each opioid receptor. ${ }^{19}$

Development of selective DOR antagonists stemmed from modification of the endogenous dermorphins (MOR agonists) and deltorphins (DOR agonists), the most selective opioid peptides known in the mid-1990s. Two residues $-\mathrm{Tyr}^{1}$ and $\mathrm{Phe}^{3}-$ of the common Nterminal tripeptide sequence (Tyr-D-Xaa-Phe) were identified as essential for interaction with the opioid receptors. Subsequent SAR studies led to the development of ligands without $\mathrm{Phe}^{3}$ that showed opioid activity. The first of these ligands, including Tyr-Tic- $\mathrm{NH}_{2}$, contained 1,2,3,4-tetrahydroisoquinoline carboxylate (Tic) and exhibited DOR antagonism.

${ }^{20}$ Replacement of the tyrosine residue with 2',6'-dimethyltyrosine (Dmt) resulted in exceptionally potent and selective DOR antagonists. ${ }^{21}$ Further work resulted in the creation of many new DOR antagonists based on the Dimethyltyrosine-Tetrahydroisoquinoline carboxylic acid (Dmt-Tic) peptide scaffold. ${ }^{22-24}$

More recently, the opioid field has shifted from synthesis of selective agonists and antagonists to multifunctional ligands, leaving room for the development of new generations of opioids. Because of the complex pharmacology of the opioid system, unwanted effects often result from the same interaction of an opioid ligand with its target that causes the desired effect. The development of multifunctional ligands which simultaneously act at multiple opioid receptors represents one strategy for overcoming such undesired on-target effects. ${ }^{25-28}$ The development of multifunctional opioid ligands has recently been reviewed. ${ }^{27}$ Since relatively minor structural modifications often result in significant changes in the pharmacological profiles of opioid ligands, selective scaffolds represent an important starting point for the creation and discovery of multifunctional compounds.

Through this strategy, Dmt-Tic ligands with other pharmacological profiles have been developed from this originally DOR antagonist selective scaffold. ${ }^{29-37}$ The evaluation of 
Dmt-Tic ligands with modified C-termini suggests that the DOR selectivity observed in this series is primarily imparted by the negative charge of the C-terminal carboxylate. ${ }^{38}$ The removal or modification of this moiety results in a Dimethyltyrosine-Tetrahydroisoquinoline (Dmt-Tiq) core useful in the development of multifunctional ligands (Figure 1).

Despite the plethora of Dmt-Tiq compounds that have been reported, modifications to this scaffold have been limited by the constraints of traditional peptide synthesis. As a result, substitution on the tetrahydroisoquinoline (Tiq) aromatic ring has been largely underexplored. In 2000, Page et. al. reported a series of DOR antagonist Dmt-Tic compounds with substitutions at the 6-, 7-, and 8-positions of Tiq ranging from hydroxy and methoxy substituents to aryl rings. ${ }^{24}$ In the same year, Santagada et. al. published Dmt-Tiq compounds with small substituents at the 7-position of Tiq which showed a similar DOR antagonist profile to the standard peptide. ${ }^{39}$ Overall, a severely limited range of substitutions has been reported at these positions, and for these compounds there remain gaps in the knowledge of their binding and efficacy.

Given this gap, we set out to explore the structure-activity relationships between the aromatic region of Tiq within the Dmt-Tiq scaffold and its opioid profile by synthesizing novel Dmt-Tiq analogues with substitution on the Tiq aromatic ring.

\section{Results and Discussion}

To investigate the SAR of the tetrahydroisoquinoline aromatic region of the Dmt-Tiq scaffold, we synthesized novel Dmt-Tiq analogues and investigated their binding and efficacy profiles at KOR, MOR, and DOR. Binding at each receptor was evaluated by competitive displacement of $\left[{ }^{3} \mathrm{H}\right]$ diprenorphine, and efficacy and potency were determined by a $\left.{ }^{35} \mathrm{~S}\right] \mathrm{GTP} \gamma \mathrm{S}$ binding assay. Reported percent stimulation values are from comparison to a standard agonist for each receptor and are used as a surrogate for efficacy. Initial exploration began with synthesis of analogues with substituents larger than those previously reported.

A benzyl pendant was installed onto each available carbon of the Tiq aromatic ring of the DOR antagonist Dmt-Tiq scaffold. Each of these analogues 4a-4d (Table 1) showed single to triple digit nanomolar binding at each of the opioid receptors. At both KOR and MOR, $\mathbf{4 c}$ bound tightest, followed by $\mathbf{4 b}$ and $\mathbf{4 d}$, with $4 \mathbf{a}$ having the lowest affinity for these two receptors. The binding profiles of these compounds at DOR differed from the other receptors, with all analogues displaying similar single digit nanomolar binding except for 4d, which had much lower affinity for DOR. None of these compounds displayed agonism at MOR or DOR; however, the efficacy profile at KOR differed widely. While $\mathbf{4 a}$ and $\mathbf{4 b}$ displayed no KOR agonism, $\mathbf{4} \mathbf{c}$ showed potent, full (85\%) agonism at KOR, and $\mathbf{4 d}$ showed weak, partial (46\%) agonism at KOR. The compounds which bind best at KOR, $\mathbf{4 c}$ and $\mathbf{4 d}$, also show the highest efficacy at this receptor.

To our knowledge, $\mathbf{4 c}$ is the first reported compound in the classically DOR antagonist selective Dmt-Tiq series which exhibits high KOR agonist activity. Based on this interesting profile - potent, full KOR agonism and high opioid receptor binding affinity - we decided to 
use $\mathbf{4 c}$ as a starting point to further explore the SAR of this series. To investigate steric and electronic effects of 7-benzyl pendant substitutions on opioid binding and activity, we synthesized analogues of $\mathbf{4 c}$ with various functional groups installed at each position of the phenyl ring. We introduced a methyl group at each position to test the steric effects of para, meta, and ortho substitutions. To further probe electronic effects at these positions, we used a nitro group (electron withdrawing, hydrogen bond accepting) and an amino group (electron donating, hydrogen bond donating). Table 2 shows binding and efficacy data for substituted 7-benzyl pendant Dmt-Tiq analogues 10a-10i.

Para substitutions (10a-10c) decreased KOR binding and resulted in a loss of KOR efficacy versus lead compound $\mathbf{4} \mathbf{c}$ with no significant gain in MOR or DOR binding or agonism. Analogues with a meta or ortho substituent (10d-10i) displayed binding profiles similar to that of parent $\mathbf{4 c}$, mostly in the single digit nanomolar range at KOR, MOR, and DOR, with the notable exception of meta and ortho amino analogues (10f, 10i) which showed an approximately tenfold decrease in binding affinity at KOR versus $\mathbf{4 c}$. Overall, however, small meta and ortho substitutions are accommodated by the orthosteric site of each opioid receptor. Meta substitutions (10d-10f) all retained some degree of KOR agonism. Methyl and nitro substitutions at the meta position (10d, 10e) retained high (>75\%) KOR efficacy while the amino analogue (10f) displayed only partial (24\%) KOR agonism. The meta methyl analogue (10d) also displayed partial (30\%) MOR agonism, while the nitro and amino analogues did not. Ortho substitutions (10g-10i) all retained high (>75\%) KOR efficacy, suggesting that small substituents at this position are allowed by the active conformation of KOR. Methyl (10g) and amino (10i) analogues not only displayed higher KOR efficacy than lead compound $\mathbf{4} \mathbf{c}$ but also introduced partial (21-27\%) MOR agonism.

Overall, no strong trend is seen with electron withdrawing or electron donating groups on the 7-benzyl pendant. As such, the pharmacological profiles of these compounds are likely more influenced by steric, space-filling effects in the opioid receptor binding sites than specific, electronic interactions. To further investigate interactions of this series of Dmt-Tiq compounds with the opioid receptors, we employed computational models similar to those previously developed ${ }^{40,41}$ and used ${ }^{42,43}$ by our group. As expected, for each compound docked, the protonated nitrogen of Dmt is shown to interact with Asp138 of KOR. Figure 3 shows each of the methyl-substituted analogues $(\mathbf{1 0 a}, \mathbf{1 0 d}, \mathbf{1 0 g})$ docked in the recent crystal structure of KOR in the active conformation (PDB ID: 6b73). ${ }^{44}$ The drastic decrease in KOR binding affinity and efficacy for para substituted analogues compared to lead compound $\mathbf{4 c}$ is likely due to a lack of space in the KOR binding site. As shown, the para methyl group of 10a causes a steric clash with V118 and W124 in the active configuration of KOR, suggesting that para substitutions are unfavorable for KOR agonism and binding. However, the meta and ortho methyl groups of $10 \mathrm{~d}$ and $10 \mathrm{~g}$ respectively are directed towards a different area of the binding site where there is space for them to be accommodated.

Several of the compounds in this series display a multifunctional KOR agonist/MOR partial agonist profile. Evidence suggests that a ligand with this profile may be useful in the treatment of cocaine addiction. ${ }^{45-47}$ It has previously been demonstrated that KOR agonists have the potential to reduce cocaine self-administration in non-human primates. ${ }^{48,49}$ However, negative side effects such as dysphoria are associated with activation of KOR, so 
the clinical utility of selective KOR ligands is limited. Since MOR agonists cause euphoria, it has been suggested that partial MOR agonism may mitigate dysphoria associated with KOR agonism, increasing the therapeutic potential of a KOR agonist. ${ }^{46,50-52}$ This work represents progress towards the development of multifunctional KOR/MOR ligands which can be investigated for this purpose.

Three compounds from this series $(\mathbf{1 0 d}, \mathbf{1 0 g}, \mathbf{1 0 i})$ display this multifunctional KOR/MOR profile. Notably, the KOR potency and MOR potency of $10 \mathrm{~g}$ and $10 \mathrm{~d}$ are higher than that of the 10i, making them the most promising KOR/MOR ligands in this series. These compounds show little to no selectivity for KOR and MOR over DOR; however, there is evidence from our group and others to suggest that DOR antagonist activity may help mitigate the addictive potential of MOR agonists. ${ }^{53-59}$ Since none of the compounds reported here show agonism at DOR, this lack of selectivity may be beneficial for the development of a therapeutic.

Future efforts will explore the incorporation of additional and larger ortho and meta substituents and modification of the methylene linker between the 7-position pendant and the Tiq core with the primary goals of increasing MOR efficacy and improving the drug-like properties of these compounds. In addition, promising compounds from this series will be evaluated in vivo for opioid activity.

In conclusion, we have repurposed a selective DOR antagonist scaffold to develop a series of novel multifunctional opioid peptidomimetics by investigating previously unexplored chemical space. The addition of a 7-benzyl pendant to the Tiq aromatic ring of Dmt-Tiq introduced strong KOR agonism. The introduction of ortho and meta substituents on the 7benzyl pendant resulted in retention of KOR agonism and addition of partial MOR agonism, a profile which has shown promise for the treatment of cocaine addiction.

\section{Methods}

\section{Synthesis}

Unless otherwise noted, all reagents and solvents were purchased from commercial sources and used without additional purification. DiBoc-Dmt was prepared from commercially available Dmt according to standard procedures. ${ }^{43,60}$ Microwave reactions were performed in a CEM Discover SP microwave synthesizer in a closed vessel with maximum power input of $300 \mathrm{~W}$. Column chromatography was carried out on silica gel cartridges using a Biotage Isolera One flash purification system. Before chromatographic purification, crude reaction mixtures were analyzed by thin layer chromatography in hexanes/ethyl acetate. Purification of final compounds was performed using a Waters semipreparative HPLC with a Vydac protein and peptide $\mathrm{C} 18$ reverse phase column using a linear gradient of $100 \%$ solvent $\mathrm{A}$ (water with $0.1 \%$ TFA) to $100 \%$ solvent B (acetonitrile with $0.1 \%$ TFA) at a rate of $1 \%$ per minute with UV absorbance monitored at $230 \mathrm{~nm}$. Purity of final compounds was determined on a Waters Alliance 2690 analytical HPLC with a Vydac protein and peptide C18 reverse phase column using the same gradient with UV absorbance monitored at 230 $\mathrm{nm}$. Purity of final compounds used for testing was $\geq 95 \%$ as determined by HPLC. ${ }^{1} \mathrm{H}$ NMR data for intermediates and final compounds in $\mathrm{CDCl}_{3}$ or $\mathrm{CD}_{3} \mathrm{OD}$ was obtained on a 400 
MHz or $500 \mathrm{MHz}$ Varian spectrometer. LC-MS data was obtained using an Agilent 6130 LC-MS in positive ion mode. HRMS data was obtained using an Agilent QTOF HPLC-MS in positive ion mode. Detailed synthetic procedures and characterization data can be found in the Supporting Information.

\section{Synthesis of Benzyl Pendant Dmt-Tiq Analogues 4a-d.}

Analogues 4a-4d were prepared according to the synthetic route shown in Scheme 1. Commercially available bromo-substituted tetrahydroisoquinolines 1a-1d were Bocprotected, and the resulting bromides $\mathbf{2 a - 2 d}$ were coupled to benzylboronic acid pinacol ester via Suzuki reaction to produce intermediates 3a-3d. Deprotection of the tetrahydroisoquinoline nitrogen with hydrochloric acid, peptide coupling with diBocprotected dimethyltyrosine, and subsequent deprotection with trifluoroacetic acid yielded peptidomimetics $\mathbf{4 a - 4 d}$.

\section{Synthesis of Substituted 7-Benzyl Pendant Dmt-Tiq Analogues 10g and 10i.}

Analogues 10g and 10i were prepared according to the first synthetic route shown in Scheme 2. Commercially available $\mathbf{5}$ was reduced with borane dimethylsulfide to secondary alcohol 6 which was then converted to the corresponding secondary bromide 7 via Appel reaction. Suzuki coupling of $\mathbf{7}$ with 2-methylphenylboronic acid or 2-aminophenylboronic acid produced intermediate $9 \mathrm{e}$ or $9 \mathrm{~g}$. Deprotection of the tetrahydroisoquinoline nitrogen with hydrochloric acid, peptide coupling with diBoc-protected dimethyltyrosine, and subsequent deprotection with trifluoroacetic acid yielded peptidomimetic $10 \mathrm{~g}$ or $\mathbf{1 0 i}$.

\section{Synthesis of Substituted 7-Benzyl Pendant Dmt-Tiq Analogues 10a-10f, 10h.}

Analogues 10a-10f and $10 \mathrm{~h}$ were prepared according to the second synthetic route shown in Scheme 2. Common intermediate $\mathbf{8}$ was prepared from $\mathbf{2 c}$. Suzuki coupling of $\mathbf{8}$ with various substituted benzyl bromides yielded intermediates 9a-9d and 9 f. Deprotection of the tetrahydroisoquinoline nitrogen with hydrochloric acid, peptide coupling with diBocprotected dimethyltyrosine, and subsequent deprotection with trifluoroacetic acid yielded peptidomimetics 10a, 10b, 10d, 10e, and 10h. For peptidomimetics 10c and 10f, reduction of the nitro group with zinc dust and ammonium chloride in acetone and water was performed prior to final deprotection.

\section{In Vitro Characterization}

Unless otherwise noted, all tissue culture reagents and radiolabeled ligands were purchased from commercial sources.

\section{Cell Lines and Membrane Preparations.}

Membranes prepared from transfected C6 rat glioma cells stably expressing rat MOR or rat DOR or Chinese Hamster Ovary cells stably expressing human KOR were used for all assays. Cells were grown to confluence at $37{ }^{\circ} \mathrm{C}$ in $5 \% \mathrm{CO}_{2}$ in Dulbecco's Modified Eagle's Medium containing $10 \% v / v$ fetal bovine serum and $5 \% \mathrm{v} / \mathrm{v}$ penicillin/streptomycin. Membranes were prepared by washing confluent cells three times with ice cold phosphatebuffered saline ( $0.9 \% \mathrm{NaCl}, 0.61 \mathrm{mM} \mathrm{Na}_{2} \mathrm{HPO}_{4}, 0.38 \mathrm{mM} \mathrm{KH}_{2} \mathrm{PO}_{4}, \mathrm{pH}$ 7.4). Cells were 
detached from the plates by incubation in warm harvesting buffer (20 mM HEPES, $150 \mathrm{mM}$ $\mathrm{NaCl}, 0.68 \mathrm{mM}$ EDTA, pH 7.4) and pelleted by centrifugation at 200xg for 3 minutes. The cell pellet was suspended in ice-cold $50 \mathrm{mM}$ Tris-HCl buffer, $\mathrm{pH} 7.4$ and homogenized with a Tissue Tearor (Biospec Products, Inc) for 20 seconds at setting 4. The homogenate was centrifuged at $20,000 \mathrm{xg}$ for 20 minutes at $4{ }^{\circ} \mathrm{C}$, and the pellet was rehomogenized in $50 \mathrm{mM}$ Tris- $\mathrm{HCl} \mathrm{pH} 7.4$ with a Tissue Tearor for 10 seconds at setting 2, followed by recentrifugation. The final pellet was resuspended in $50 \mathrm{mM}$ Tris- $\mathrm{HCl} \mathrm{pH} 7.4$ and frozen in aliquots at $-80^{\circ} \mathrm{C}$. Protein concentration was determined via Pierce BCA protein assay kit using bovine serum albumin as the standard.

\section{Binding Affinity.}

Binding affinities for peptidomimetics 4a-4d and 10a-10i at KOR, MOR, and DOR were determined by competitive displacement of $\left[{ }^{3} \mathrm{H}\right]$ diprenorphine as previously reported. 43,61-63 In a 96-well plate format, cell membranes (20 $\mu \mathrm{g}$ of protein) and $\left[{ }^{3} \mathrm{H}\right]$ diprenorphine $(0.2 \mathrm{nM})$ were incubated in Tris- $\mathrm{HCl}$ buffer $(50 \mathrm{mM}, \mathrm{pH} 7.4)$ with various concentrations of test compound at $25{ }^{\circ} \mathrm{C}$ for 1 hour, allowing the mixture to reach equilibrium. Nonspecific binding was determined using the opioid antagonist naloxone $(10 \mu \mathrm{M})$, and total binding was determined using vehicle in the absence of competitive ligand. After incubation, membranes were filtered through Whatman GF/C 1.2 micron glass fiber filters and washed with $50 \mathrm{mM}$ Tris-HCl buffer. The radioactivity remaining on the filters was then quantified by liquid scintillation counting after saturation with EcoLume liquid scintillation cocktail in a PerkinElmer Microbeta 2450. Binding affinity $\left(\mathrm{K}_{\mathrm{i}}\right)$ values were calculated using the Cheng-Prusoff equation via nonlinear regression analysis using GraphPad Prism software from at least three separate binding assays performed in duplicate.

\section{Stimulation of $\left[{ }^{35} \mathrm{~S}\right] \mathrm{GTP} \gamma \mathrm{S}$ Binding.}

Agonist stimulation of KOR, MOR, and DOR by peptidomimetics $4 \mathbf{a}-\mathbf{4 d}$ and $\mathbf{1 0 a - 1 0 i}$ was determined by $\left[{ }^{35}\right.$ S $]$ guanosine $5^{\prime}$-O- $[\gamma$-thio $]$ triphosphate $\left(\left[{ }^{35} \mathrm{~S}\right] \mathrm{GTP} \gamma \mathrm{S}\right)$ binding assays as previously reported. ${ }^{43,61-63}$ In a 96-well plate format, membranes from cells expressing opioid receptors as described above (10 $\mu$ g of protein), $\left[{ }^{35} \mathrm{~S}\right] \mathrm{GTP} \gamma \mathrm{S}(0.1 \mathrm{nM})$, and guanosine diphosphate $(30 \mu \mathrm{M})$ were incubated in GTP $\gamma \mathrm{S}$ buffer $(50 \mathrm{mM}$ Tris- $\mathrm{HCl}, 100$ $\mathrm{mM} \mathrm{NaCl}, 5 \mathrm{mM} \mathrm{MgCl} 2,1 \mathrm{mM}$ EDTA, $\mathrm{pH}$ 7.4) with various concentrations of test compound at $25^{\circ} \mathrm{C}$ for 1 hour. Basal stimulation was determined by incubation in the absence of any ligand. After incubation, membranes were filtered through Whatman GF/C 1.2 micron glass fiber filters and washed with GTP $\gamma \mathrm{S}$ buffer with no EDTA. The radioactivity remaining on the filters was then quantified by liquid scintillation counting after saturation with EcoLume liquid scintillation cocktail in a Perkin-Elmer Microbeta 2450. Data are reported as percent stimulation compared to the effects of $10 \mu \mathrm{M}$ standard agonist - U69,593 (KOR), DAMGO (MOR), or DPDPE (DOR). Percent stimulation and $\mathrm{EC}_{50}$ values were determined via nonlinear regression analysis using GraphPad Prism software from at least three separate assays performed in duplicate. Efficacy is expressed as percent stimulation relative to standard agonist. 


\section{Computational Modeling}

Modeling of three-dimensional (3D) structures of receptor-ligand complexes was based on the available X-ray structure of the human KOR in the active conformation (PDB ID: 6b73). ${ }^{44}$ Structures of peptidomimetic ligands were generated using the 3D-Builder Application of QUANTA (Accelrys, Inc.) followed by Conformational Search included in the program package. Low-energy ligand conformations (within $2 \mathrm{kcal} / \mathrm{mol}$ ) that demonstrated the best superposition of aromatic substituents of the tetrahydroisoquinoline core with the pharmacophore elements $\left(\mathrm{Tyr}^{1}\right.$ and $\mathrm{Phe}^{3}$ ) of receptor-bound conformations of cyclic tetrapeptides ${ }^{64}$ were selected for docking into the receptor binding pocket. Ligands were positioned inside the receptor binding cavity to reproduce the binding modes of cyclic tetrapeptides and co-crystalized ligands in MOR and KOR X-ray structures. Two conformations of peptidomimetics were tested: with the peptide bond in cis $\left(\omega=0^{\circ}\right)$ and trans $\left(\omega=180^{\circ}\right)$ configurations. Though ligands with a cis peptide group have slightly higher conformational energy (by $\sim 1 \mathrm{kcal} / \mathrm{mol}$ ), they fit better in the ligand binding pockets of the receptors, overlapping with ligands co-crystalized with KOR and MOR. The docking pose of each ligand was subsequently refined using the solid docking module of QUANTA. Models of opioid ligand-receptor complexes are available upon request.

\section{Supplementary Material}

Refer to Web version on PubMed Central for supplementary material.

\section{Acknowledgments}

Funding Sources

This study was supported by NIH grant DA003910. Resources were provided by the Edward F. Domino Research Center. DM was supported by an ACS MEDI Pre-doctoral Fellowship. NWG was supported by the NIDA Training Program in Neuroscience (NTPiN) DA007281-22. IP was supported by NSF grant DBI-1458002.

\section{Abbreviations}

$\begin{array}{ll}\text { 6Cl-HOBt } & \text { 6-chlorohydroxybenzotriazole } \\ \text { Boc2 } & \text { di-tert-butyl dicarbonate } \\ \text { DCM } & \text { dichloromethane } \\ \text { DiBoc-Dmt } & \text { tert-Butoxycarbonyl-protected-L-2,6-dimethyltyrosine } \\ \text { DIEA } & \text { diisopropylethylamine } \\ \text { DMF } & \text { dimethylformamide } \\ \text { DMSO } & \text { dimethylsulfoxide } \\ \text { Dmt-Tic } & \text { dimethyltyrosine-tetrahydroisoquinoline carboxylic acid } \\ \text { Dmt-Tiq } & \text { dimethyltyrosine-tetrahydroisoquinoline } \\ \text { DOR } & \text { delta opioid receptor }\end{array}$




$\begin{array}{ll}\text { GTP } \boldsymbol{\gamma} \text { S } & \text { guanosine 5'-O-[} \boldsymbol{\gamma} \text {-thio]triphosphate } \\ \text { KOR } & \text { kappa opioid receptor } \\ \text { MOR } & \text { mu opioid receptor } \\ \text { PyBOP } & \text { benzotriazol-1-yloxytripyrrolidinophosphonium hexafluorophosphate } \\ \text { SAR } & \text { structure-activity relationships } \\ \text { TFA } & \text { trifluoroacetic acid } \\ \text { THF } & \text { tetrahydrofuran } \\ \text { Tic } & \text { tetrahydroisoquinoline carboxylate } \\ \text { Tiq } & \text { tetrahydroisoquinoline }\end{array}$

\section{References}

(1). Aldrich JV; McLaughlin JP Opioid Peptides: Potential for Drug Development. Drug Discov. Today Technol. 2012, 9 (1), e23-e31. [PubMed: 23316256]

(2). Stein C Opioid Receptors. Annu. Rev. Med. 2016, 67, 433-451. [PubMed: 26332001]

(3). Chan HCS; McCarthy D; Li J; Palczewski K; Yuan S Designing Safer Analgesics via $\mu$-Opioid Receptor Pathways. Trends Pharmacol. Sci. 2017, 38 (11), 1016-1037. [PubMed: 28935293]

(4). Chavkin C; Koob GF Dynorphin, Dysphoria, and Dependence: The Stress of Addiction. Neuropsychopharmacol. Rev. 2016, 41 (1), 373-374.

(5). Dripps IJ; Jutkiewicz EM Delta Opioid Receptors and Modulation of Mood and Emotion Delta Opioid Recept. Pharmacol. Ther. Appl. 2017, Handbook o, 179-197.

(6). Nummenmaa L; Tuominen L Opioid System and Human Emotions. Br. J. Pharmacol. 2018, 175 (14), 2737-2749. [PubMed: 28394427]

(7). Merrer JLE; Becker JAJ; Befort K; Kieffer BL Reward Processing by the Opioid System in the Brain. Physiol Rev 2009, 89, 1379-1412. [PubMed: 19789384]

(8). Lalanne L; Ayranci G; Kieffer BL; Lutz P-E The Kappa Opioid Receptor: From Addiction to Depression, and Back. Front. psychiatry 2014, 5 (December), 170. [PubMed: 25538632]

(9). Nummenmaa L; Saanijoki T; Tuominen L; Hirvonen J; Tuulari JJ; Nuutila P; Kalliokoski K MOpioid Receptor System Mediates Reward Processing in Humans. Nat. Commun. 2018, 9 (1500), 1-7. [PubMed: 29317637]

(10). Henry MS; Gendron L; Tremblay M-E; Drolet G Enkephalins: Endogenous Analgesics with an Emerging Role in Stress Resilience. Neural Plast. 2017, 1-11.

(11). Boom M; Niesters M; Sarton E; Aarts L; Smith TW; Dahan A Non-Analgesic Effects of Opioids: Opioid-Induced Respiratory Depression. Curr. Pharm. Des. 2012, 18 (37), 5994-6004. [PubMed: 22747535]

(12). Imam MZ; Kuo A; Ghassabian S; Smith MT Progress in Understanding Mechanisms of OpioidInduced Gastrointestinal Adverse Effects and Respiratory Depression. Neuropharmacology 2018, 131, 238-255. [PubMed: 29273520]

(13). Camilleri M; Lembo A; Katzka DA Opioids in Gastroenterology: Treating Adverse Effects and Creating Therapeutic Benefits. Clin. Gastroenterol. Hepatol. 2017, 15 (9), 1338-1349. [PubMed: 28529168]

(14). Janecka A; Fichna J; Janecki T Opioid Receptors and Their Ligands: Recent Developments. Curr. Top. Med. Chem. 2004, 4, 1-17. [PubMed: 14754373]

(15). Janecka A; Perlikowska R; Gach K; Wyrebska A; Fichna J Development of Opioid Peptide Analogs for Pain Relief. Curr. Pharm. Des. 2010, 16 (9), 1126-1135. [PubMed: 20030621] 
(16). Gentilucci L New Trends in the Development of Opioid Peptide Analogues as Advanced Remedies for Pain Relief. Curr. Top. Med. Chem. 2004, 4 (1), 19-38. [PubMed: 14754374]

(17). Hruby VJ; Cai M Design of Peptide and Peptidomimetic Ligands with Novel Pharmacological Activity Profiles. Annu. Rev. Pharmacol. Toxicol. 2013, 53 (1), 557-580. [PubMed: 23294313]

(18). Hruby VJ Multivalent Peptide and Peptidomimetic Ligands for the Treatment of Pain without Toxicities and Addiction. Peptides 2019, 116 (April), 63-67. [PubMed: 31014958]

(19). Eguchi M Recent Advances in Selective Opioid Receptor Agonists and Antagonists. Med. Res. Rev. 2004, 24 (2), 182-212. [PubMed: 14705168]

(20). Salvadori S; Attila M; Balboni G; Bianchi C; Bryant SD; Crescenzi O; Guerrini R; Picone D; Tancredi T; Temussi PA; et al. Delta Opioidmimetic Antagonists: Prototypes for Designing a New Generation of Ultraselective Opioid Peptides. Mol. Med. 1995, 1 (6), 678-689. [PubMed: 8529134]

(21). Capasso A; Guerrini R; Balboni G; Sorrentino L; Temussi P; Lazarus LH; Bryant SD; Salvadori $\mathrm{S}$; Communication A DMT-TIC-OH, A Highly Selective and Potent Delta-Opioid Dipeptide Receptor Antagonist After Systemic Administration in the Mouse. Pharmacol. Lett. 1996, 59 (8), PL 93-98.

(22). Salvadori S; Balboni G; Guerrini R; Tomatis R; Bianchi C; Bryant SD; Cooper PS; Lazarus LH Evolution of the Dmt-Tic Pharmacophore: N-Terminal Methylated Derivatives with Extraordinary Delta Opioid Antagonist Activity. J. Med. Chem. 1997, 40 (19), 3100-3108. [PubMed: 9301674]

(23). Bryant SD; Salvadori S; Cooper PS; Lazarus LH New Delta-Opioid Antagonists as Pharmacological Probes. Trends Pharmacol. Sci. 1998, 19 (2), 42-46. [PubMed: 9550939]

(24). Pagé D; McClory A; Mischki T; Schmidt R; Butterworth J; St-Onge S; Labarre M; Payza K; Brown W Novel Dmt-Tic Dipeptide Analogues as Selective Delta-Opioid Receptor Antagonists. Bioorganic Med. Chem. Lett. 2000, 10 (2), 167-170.

(25). Dietis N; Guerrini R; Calo G; Salvadori S; Rowbotham DJ; Lambert DG Simultaneous Targeting of Multiple Opioid Receptors: A Strategy to Improve Side-Effect Profile. Br. J. Anaesth. 2009, 103 (1), 38-49. [PubMed: 19474215]

(26). Turnaturi R; Arico G; Ronsisvalle G; Parenti C; Pasquinucci L Multitarget Opioid Ligands in Pain Relief: New Players in an Old Game. Eur. J. Med. Chem. 2016, 108, 211-228. [PubMed: 26656913]

(27). Anand JP; Montgomery D Multifunctional Opioid Ligands. Handb. Exp. Pharmacol. 2018, 247, 21-51. [PubMed: 29675582]

(28). Schiller PW Bi- or Multifunctional Opioid Peptide Drugs. Life Sci. 2010, 86, 598-603. [PubMed: 19285088]

(29). Pagé D; Naismith A; Schmidt R; Coupal M; Labarre M; Gosselin M; Bellemare D; Payza K; Brown W Novel C-Terminus Modifications of the Dmt-Tic Motif: A New Class of Dipeptide Analogues Showing Altered Pharmacological Profiles toward the Opioid Receptors. J. Med. Chem. 2001, 44 (15), 2387-2390. [PubMed: 11448220]

(30). Balboni G; Fiorini S; Baldisserotto A; Trapella C; Sasaki Y; Ambo A; Marczak ED; Lazarus LH; Salvadori S Further Studies on Lead Compounds Containing the Opioid Pharmacophore DmtTic. J. Med. Chem. 2008, 51 (16), 5109-5117. [PubMed: 18680274]

(31). Wentland MP; Sun X; Ye Y; Lou R; Bidlack JM Redefining the Structure-Activity Relationships of 2,6-Methano-3-Benzazocines. Part 2: 8-Formamidocyclazocine Analogues. Bioorganic Med. Chem. Lett. 2003, 13 (11), 1911-1914.

(32). Balboni G; Guerrini R; Salvadori S; Bianchi C; Rizzi D; Bryant SD; Lazarus LH Evaluation of the Dmt-Tic Pharmacophore: Conversion of a Potent Delta-Opioid Receptor Antagonist into a Potent Delta Agonist and Ligands with Mixed Properties. J. Med. Chem. 2002, 45 (3), 713-720. [PubMed: 11806723]

(33). Labarre M; Butterworth J; St-Onge S; Payza K; Schmidhammer H; Salvadori S; Balboni G; Guerrini R; Bryant SD; Lazarus LH Inverse Agonism by Dmt-Tic Analogues and HS 378, a Naltrindole Analogue. Eur. J. Pharmacol. 2000, 406 (1), 4-6. 
(34). Pagé D; Nguyen N; Bernard S; Coupal M; Gosselin M; Lepage J; Adam L; Brown W New Scaffolds in the Development of Mu Opioid-Receptor Ligands. Bioorganic Med. Chem. Lett. 2003, 13 (9), 1585-1589.

(35). Salvadori S; Trapella C; Fiorini S; Negri L; Lattanzi R; Bryant SD; Jinsmaa Y; Lazarus LH; Balboni G A New Opioid Designed Multiple Ligand Derived from the $\mu$ Opioid Agonist Endomorphin-2 and the $\delta$ Opioid Antagonist Pharmacophore Dmt-Tic. Bioorganic Med. Chem. 2007, 15 (22), 6876-6881.

(36). Balboni G; Salvadori S; Trapella C; Knapp BI; Bidlack JM; Lazarus LH; Peng X; Neumeyer JL Evolution of the Bifunctional Lead Mu Agonist/Delta Antagonist Containing the 2',6'-DimethylL-Tyrosine-1,2,3,4-Tetrahydroisoquinoline-3-Carboxylic Acid (Dmt-Tic) Opioid Pharmacophore. ACS Chem. Neurosci. 2010, 1 (2), 155-164. [PubMed: 20352071]

(37). Balboni G; Salvadori S; Marczak ED; Knapp BI; Bidlack JM; Lazarus LH; Peng X; Si YG; Neumeyer JL Opioid Bifunctional Ligands from Morphine and the Opioid Pharmacophore DmtTic. Eur. J. Med. Chem. 2011, 46 (2), 799-803. [PubMed: 21216504]

(38). Balboni G; Salvadori S; Guerrini R; Negri L; Giannini E; Bryant SD; Jinsmaa Y; Lazarus LH Direct Influence of C-Terminally Substituted Amino Acids in the Dmt-Tic Pharmacophore on Delta-Opioid Receptor Selectivity and Antagonism. J. Med. Chem. 2004, 47 (16), 4066-4071. [PubMed: 15267245]

(39). Santagada V; Balboni G; Caliendo G; Guerrini R; Salvadori S; Bianchi C; Bryant SD; Lazarus LH Assessment of Substitution in the Second Pharmacophore of Dmt-Tic Analogues. Bioorg. Med. Chem. Lett. 2000, 10 (24), 2745-2748. [PubMed: 11133082]

(40). Pogozheva ID; Lomize AL; Mosberg HI Opioid Receptor Three-Dimensional Structures from Distance Geometry Calculations with Hydrogen Bonding Constraints. Biophys. J. 1998, 75 (2), 612-634. [PubMed: 9675164]

(41). Fowler CB; Pogozheva ID; LeVine H; Mosberg HI Refinement of a Homology Model of the $\mu$ Opioid Receptor Using Distance Constraints from Intrinsic and Engineered Zinc-Binding Sites. Biochemistry 2004, 43 (27), 8700-8710. [PubMed: 15236578]

(42). Anand JP; Porter-Barrus VR; Waldschmidt HV; Yeomans L; Pogozheva ID; Traynor JR; Mosberg HI Translation of Structure-Activity Relationships from Cyclic Mixed Efficacy Opioid Peptides to Linear Analogues. Biopolym. Pept. Sci. 2014, 102 (1), 107-114.

(43). Harland AA; Bender AM; Griggs NW; Gao C; Anand JP; Pogozheva ID; Traynor JR; Jutkiewicz EM; Mosberg HI Effects of N-Substitutions on the Tetrahydroquinoline (THQ) Core of MixedEfficacy $\mu$-Opioid Receptor (MOR)/ $\delta$-Opioid Receptor (DOR) Ligands. J. Med. Chem. 2016, 59 (10), 4985-4998. [PubMed: 27148755]

(44). Che T; Majumdar S; Zaidi SA; Ondachi P; McCorvy JD; Wang S; Mosier PD; Uprety R; Vardy E; Krumm BE; et al. Structure of the Nanobody-Stabilized Active State of the Kappa Opioid Receptor. Cell 2018, 172 (1-2), 55-67. [PubMed: 29307491]

(45). Bowen CA; Stevens Negus S; Zong R; Neumeyer JL; Bidlack JM; Mello NK Effects of MixedAction Kappa/Mu Opioids on Cocaine Self-Administration and Cocaine Discrimination by Rhesus Monkeys. Neuropsychopharmacology 2003, 28, 1125-1139. [PubMed: 12637953]

(46). Neumeyer JL; Bidlack JM; Zong R; Bakthavachalam V; Gao P; Cohen DJ; Negus SS; Mello NK Synthesis and Opioid Receptor Affinity of Morphinan and Benzomorphan Derivatives: Mixed Kappa Agonists and Mu Agonists/Antagonists as Potential Pharmacotherapeutics for Cocaine Dependence. J. Med. Chem. 2000, 43 (1), 114-122. [PubMed: 10633042]

(47). Neumeyer JL; Zhang A; Xiong W; Gu X-H; Hilbert JE; Knapp BI; Negus SS; Mello NK; Bidlack JM Design and Synthesis of Novel Dimeric Morphinan Ligands for Kappa and Mu Opioid Receptors. J. Med. Chem. 2003, 46 (24), 5162-5170. [PubMed: 14613319]

(48). Mello NK; Negus SS Effects of Kappa Opioid Agonists on Cocaine- and Food-Maintained Responding by Rhesus Monkeys. J. Pharmacol. Exp. Ther. 1998, 286 (2), 812-824. [PubMed: 9694938]

(49). Negus SS; Mello NK; Portoghese PS; Lin C Effects of Kappa Opioids on Cocaine SelfAdministration by Rhesus Monkeys. J. Pharmacol. Exp. Ther. 1997, 282 (1), 44-55. [PubMed: 9223538] 
(50). Zhang A; Xiong W; Bidlack JM; Hilbert JE; Knapp BI; Wentland MP; Neumeyer JL 10Ketomorphinan and 3-Substituted-3-Desoxymorphinan Analogues as Mixed Kappa and Mu Opioid Ligands: Synthesis and Biological Evaluation of Their Binding Affinity at Opioid Receptors. J. Med. Chem. 2004, 47 (1), 165-174. [PubMed: 14695830]

(51). Bidlack JM; Knapp BI Chapter 14: Mixed Mu/Kappa Opioid Agonists. In Research and Development of Opioid-Related Ligands; 2013.

(52). Bidlack J Mixed Kappa/Mu Partial Opioid Agonists as Potential Treatments for Cocaine Dependence In Advances in Pharmacology; Elsevier Inc, 2014; Vol. 69, pp 387-418. [PubMed: 24484983]

(53). Abdelhamid EE; Sultana M; Portoghese PS; Takemori AE Selective Blockage of the Delta Opioid Receptors Prevents the Development of Morphine Tolerance and Dependence in Mice. J. Pharmacol. Exp. Ther. 1991, 258 (1), 299-301. [PubMed: 1649297]

(54). Fundytus ME; Schiller PW; Shapiro M; Weltrowska G; Coderre TJ Attenuation of Morphine Tolerance and Dependence with the Highly Selective Delta-Opioid Receptor Antagonist TIPP[Psi]. Eur. J. Pharmacol. 1995, 286 (1), 105-108. [PubMed: 8566146]

(55). Schiller PW; Fundytus ME; Merovitz L; Weltrowska G; Nguten TM-D; Lemieux C; Chung NN; Coderre TJ The Opioid Mu Agonist/Delta Antagonist DIPP-NH2(Psi) Produces a Potent Analgesic Effect, No Physical Dependence and Less Tolerance than Morphine in Rats. J. Med. Chem. 1999, 42 (18), 3520-3526. [PubMed: 10479285]

(56). Hepburn MJ; Little PJ; Gringas J; Khun CM Differential Effects of Naltrindole on MorphineInduced Tolerance and Physical Dependence in Rats. J. Pharmacol. Exp. Ther. 1997, 281 (3), 1350-1356. [PubMed: 9190871]

(57). Shippenberg TS; Chefer VI; Thompson AC Delta-Opioid Receptor Antagonists Prevent Sensitization to the Conditioned Rewarding Effects of Morphine. Biol. Psychiatry 2009, 65 (2), 169-174. [PubMed: 18950747]

(58). Mosberg HI; Yeomans L; Anand JP; Porter V; Sobczyk-Kojiro K; Traynor JR; Jutkiewicz EM Development of a Bioavailable $\mu$ Opioid Receptor (MOPr) Agonist, $\delta$ Opioid Receptor (DOPr) Antagonist Peptide That Evokes Antinociception without Development of Acute Tolerance. J. Med. Chem. 2014, 57 (7), 3148-3153. [PubMed: 24641190]

(59). Anand JP; Kochan KE; Nastase AF; Montgomery D; Griggs NW; Traynor JR; Mosberg HI; Jutkiewicz EM In Vivo Effects of $\mu$-Opioid Receptor Agonist/ $\delta$-Opioid Receptor Antagonist Peptidomimetics Following Acute and Repeated Administration. Br. J. Pharmacol. 2018, 175 (11), 2013-2027. [PubMed: 29352503]

(60). Nastase AF; Griggs NW; Anand JP; Fernandez TJ; Harland AA; Trask TJ; Jutkiewicz EM; Traynor JR; Mosberg HI Synthesis and Pharmacological Evaluation of Novel C-8 Substituted Tetrahydroquinolines as Balanced-Affinity Mu/Delta Opioid Ligands for the Treatment of Pain. ACS Chem. Neurosci. 2018, 9 (7), 1840-1848. [PubMed: 29677442]

(61). Traynor JR; Nahorski SR Modulation by Mu-Opioid Agonists of Guanosine-5' -O-(3[35S]Thio)Triphosphate Binding to Membranes from Human Neuroblastoma SH-SY5Y Cells. Mol. Pharmacol. 1995, 47 (4), 848-854. [PubMed: 7723747]

(62). Lee KO; Akil H; Woods JH; Traynor JR Differential Binding Properties of Oripavines at Cloned Mu- and Delta-Opioid Receptors. Eur. J. Pharmacol. 1999, 378 (3), 323-330. [PubMed: 10493109]

(63). Harrison C; Traynor JR The [35S]GTPgammaS Binding Assay: Approaches and Applications in Pharmacology. Life Sci. 2003, 74 (4), 489-508. [PubMed: 14609727]

(64). Pogozheva ID; Przydzial MJ; Mosberg HI Homology Modeling of Opioid Receptor-Ligand Complexes Using Experimental Constraints. AAPS J. 2005, 7 (2), E434-448. [PubMed: 16353922] 


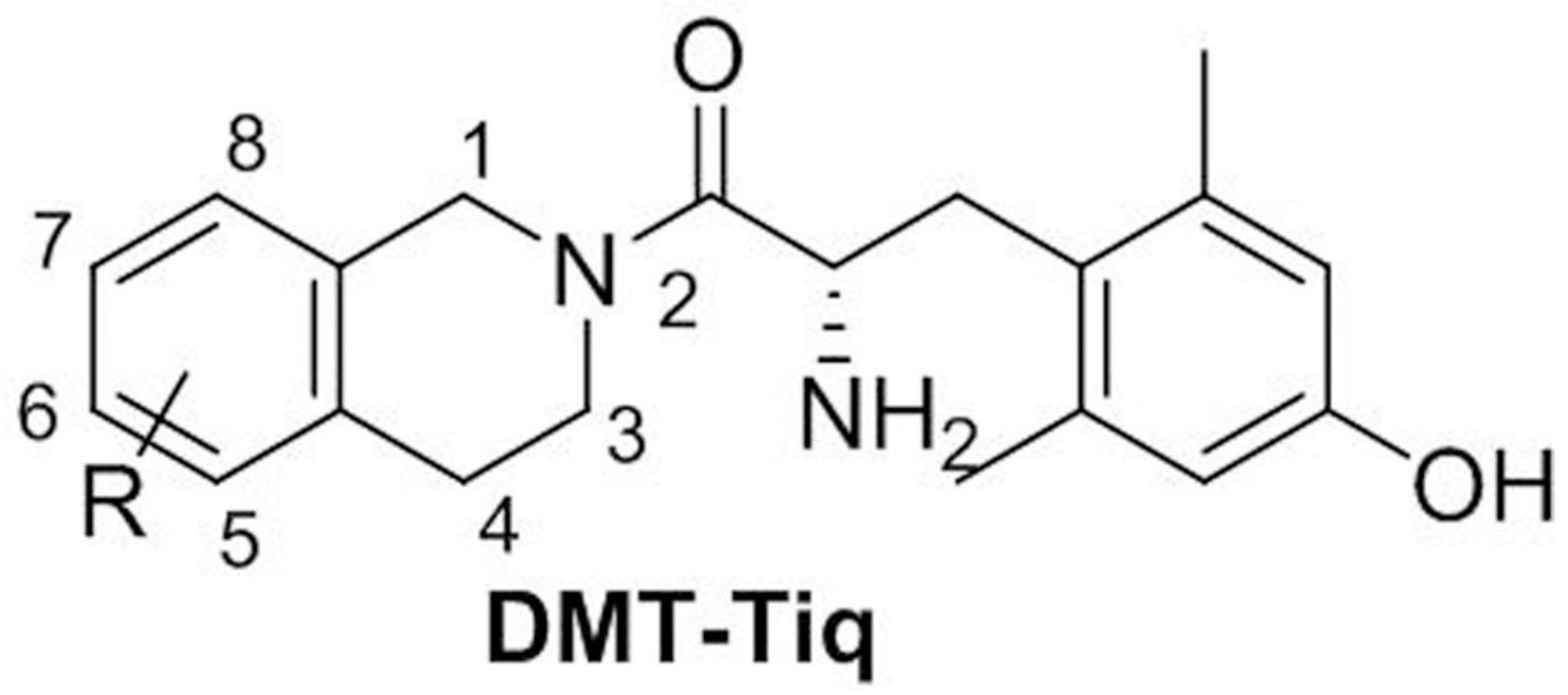

Figure 1.

Dimethyltyrosine - Tetrahydroisoquinoline (DMT-Tiq) scaffold with carbon numbering on the tetrahydroisoquinoline. 


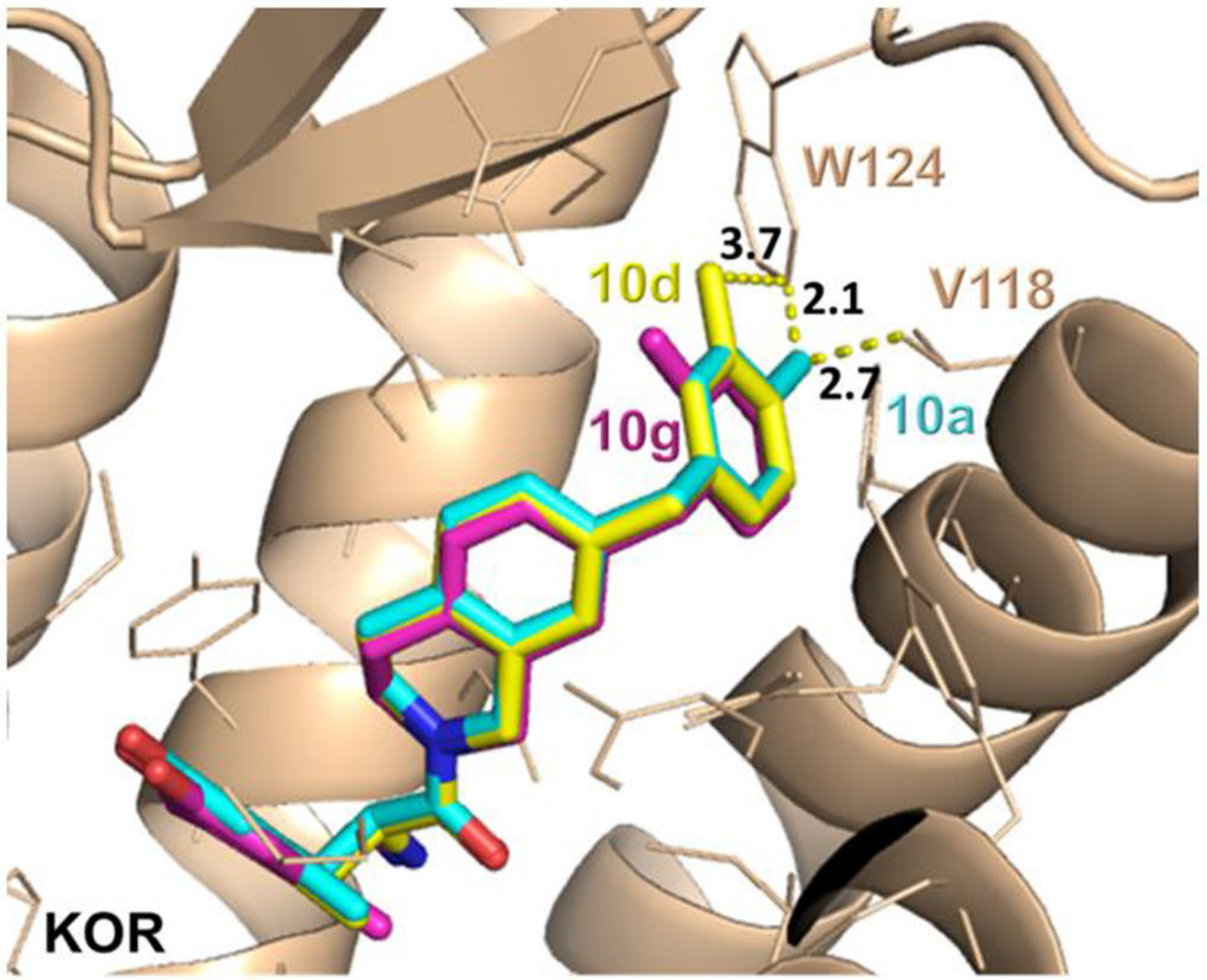

Figure 3.

10a (cyan), 10d (yellow), and $10 \mathrm{~g}$ (magenta) docked in the orthosteric site of the active conformation of KOR. Dashed yellow lines represent distance, labeled in angstroms. The para methyl group of 10a sterically clashes with V118 and W124 of KOR. 


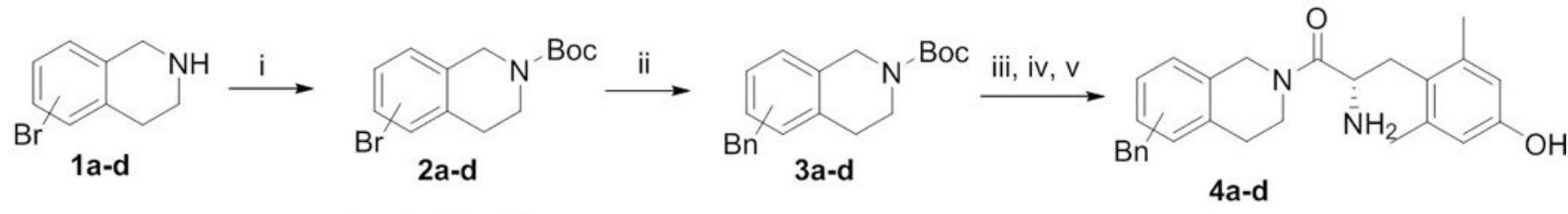

1a, $2 \mathrm{a}, \mathrm{R}=5-\mathrm{Br}$

1b, $2 b, R=6-B r$

$1 c, 2 c, R=7-B r$

3a, $4 a, R=5-B n$

1d, $2 \mathrm{~d}, \mathrm{R}=8-\mathrm{Br}$

$3 b, 4 b, R=6-B n$

$3 c, 4 c, R=7-B n$

$3 d, 4 d, R=8-B n$

Scheme 1: Synthesis of Benzyl Pendant Dmt-Tiq Analogues 4a-4d

(i) $\mathrm{Boc}_{2} \mathrm{O}$; (ii) Benzylboronic acid pinacol ester, $\mathrm{Pd}(\mathrm{dppf}) \mathrm{Cl}_{2}, \mathrm{~K}_{2} \mathrm{CO}_{3}$, acetone/water; (iii)

HCl, 1,4-dioxane; (iv) diBoc-Dmt, PyBOP, 6Cl-HOBt, DIEA, DMF; (v) TFA, DCM 
<smiles>CC(C)(C)C(=O)N1CCc2ccc(CO)cc2C1</smiles><smiles>[R]c1ccc(Cc2ccc3c(c2)CN(C(=O)OC(C)(C)C)CC3)cc1</smiles>

9a, $\mathrm{R}=\mathrm{p}-\mathrm{Me}$

$10 \mathrm{a}, \mathrm{R}=\mathrm{p}-\mathrm{Me}$

$9 b, R=p-\mathrm{NO}_{2}$

$10 b, R=p-\mathrm{NO}_{2}$

10c, $\mathrm{R}=\mathrm{p}-\mathrm{NH}_{2}$

10d, $R=m-M e$

vi, vii, viii, ix

9c, $\mathrm{R}=\mathrm{m}-\mathrm{Me}$

10e, $\mathrm{R}=\mathrm{m}-\mathrm{NO}_{2}$

9e, $\mathrm{R}=\mathrm{o}-\mathrm{Me}$

10f, $\mathrm{R}=\mathrm{m}-\mathrm{NH}_{2}$

9f, $\mathrm{R}=\mathrm{o}-\mathrm{NO}_{2}$

$10 \mathrm{~g}, \mathrm{R}=\mathrm{O}-\mathrm{Me}$

10h, $\mathrm{R}=\mathrm{o}-\mathrm{NO}_{2}$

$10 \mathrm{i}, \mathrm{R}=\mathrm{o}-\mathrm{NH}_{2}$

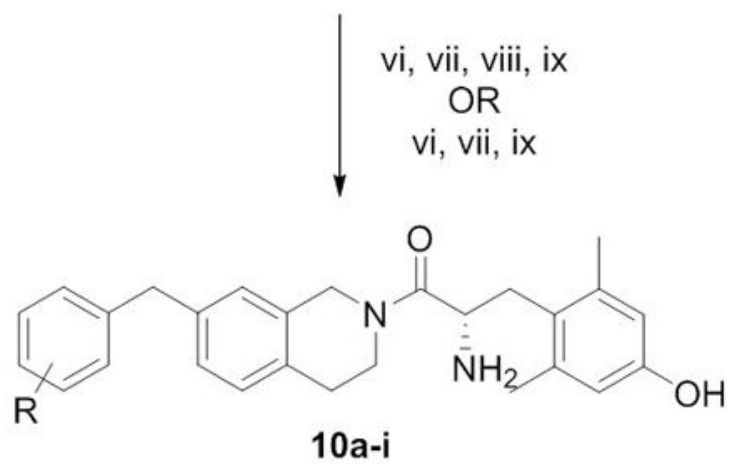

Scheme 2: Synthesis of Substituted 7-Benzyl Pendant Dmt-Tiq Analogues 10a-10i

(i) $\mathrm{BH}_{3} \mathrm{SMe}_{2}$, THF; (ii) $\mathrm{CBr}_{4}, \mathrm{PPh}_{3}$, DCM (iii) substituted benzyl bromide, $\mathrm{Pd}(\mathrm{dppf}) \mathrm{Cl}_{2}$, $\mathrm{K}_{2} \mathrm{CO}_{3}$, acetone/water; (iv) bis(pinacolato)diboron, $\mathrm{Pd}(\mathrm{dppf}) \mathrm{Cl}_{2}, \mathrm{CH}_{3} \mathrm{CO}_{2} \mathrm{~K}$, DMSO; (v) substituted aryl boronic acid, $\mathrm{Pd}$ (dppf) $\mathrm{Cl}_{2}, \mathrm{~K}_{2} \mathrm{CO}_{3}, 3: 1$ acetone:water; (vi) $\mathrm{HCl}$, 1,4-dioxane; (vii) diBoc-Dmt, PyBOP, 6Cl-HOBt, DIEA, DMF; (viii) $\mathrm{Zn}, \mathrm{NH}_{4} \mathrm{Cl}$, acetone/water; (ix) TFA, DCM 


\section{Table 1:}

Binding, Potency, and Efficacy Data for Benzyl Pendant Dmt -Tiq Analogues 4a-4d.

Binding affinity $(\mathrm{Ki})$ values determined by competitive displacement of $\left[{ }^{3} \mathrm{H}\right]$ diprenorphine in membrane preparations from rat $\mathrm{C} 6$ or human $\mathrm{CHO}$ cells expressing $\mathrm{KOR}$, MOR, or DOR. Potency $\left(\mathrm{EC}_{50}\right)$ and efficacy values determined by $\left[{ }^{35} \mathrm{~S}\right] \mathrm{GTP}{ }^{3} \mathrm{~S}$ binding in the same membrane preparations. Efficacy expressed as percent stimulation versus standard agonist - U69,593 (KOR), DAMGO (MOR), or DPDPE (DOR). All values expressed as mean (SEM) of three or more separate assays run in duplicate. $\mathrm{Bn}=$ benzyl; dns = does not stimulate, average maximal stimulation $<10 \%$ at concentrations up to $10 \mu \mathrm{M}$

\begin{tabular}{|c|c|c|c|c|c|c|c|c|c|c|}
\hline \multirow{2}{*}{$\underbrace{6}_{3 n}$} & & \multirow[b]{2}{*}{ KOR } & \multirow{2}{*}{$\begin{array}{r}\mathbf{K}_{\mathbf{i}}(\mathbf{n M}) \\
\text { MOR }\end{array}$} & \multirow[b]{2}{*}{ DOR } & \multicolumn{3}{|c|}{$\mathrm{EC}_{50}(\mathrm{nM})$} & \multicolumn{3}{|c|}{$\%$ Stimulation } \\
\hline & & & & & KOR & MOR & DOR & KOR & MOR & DOR \\
\hline $4 a$ & $5-\mathrm{Bn}$ & $112(13)$ & $17(5)$ & $3.3(0.2)$ & - & - & - & dns & dns & dns \\
\hline $4 b$ & $6-\mathrm{Bn}$ & $38(5)$ & $9.9(1.6)$ & $4.3(0.6)$ & - & - & - & dns & dns & dns \\
\hline $4 c$ & 7-Bn & $3.9(0.8)$ & $2.7(0.8)$ & $6.1(2.1)$ & $33(6)$ & - & - & $85(8)$ & dns & dns \\
\hline $4 d$ & $8-\mathrm{Bn}$ & $26(5)$ & $4.1(0.4)$ & 185 (28) & $319(45)$ & - & - & $46(6)$ & dns & dns \\
\hline
\end{tabular}


Table 2:

Binding, Potency, and Efficacy Data for Substituted 7-Benzyl Pendant Dmt -Tiq Analogues 10a-10i.

Binding affinity $(\mathrm{Ki})$ values determined by competitive displacement of $\left[{ }^{3} \mathrm{H}\right]$ diprenorphine in membrane preparations from rat $\mathrm{C} 6$ or human $\mathrm{CHO}$ cells expressing $\mathrm{KOR}, \mathrm{MOR}$, or DOR. Potency $\left(\mathrm{EC}_{50}\right)$ and efficacy values determined by $\left[{ }^{35} \mathrm{~S}\right] \mathrm{GTP} \varepsilon \mathrm{S}$ binding in the same membrane preparations. Efficacy expressed as percent stimulation versus standard agonist - U69,593 (KOR), DAMGO (MOR), or DPDPE (DOR). All values expressed as mean (SEM) of three or more separate assays run in duplicate. $\mathrm{Bn}=$ benzyl; dns = does not stimulate, average maximal stimulation $<10 \%$ at concentrations up to $10 \mu \mathrm{M}$

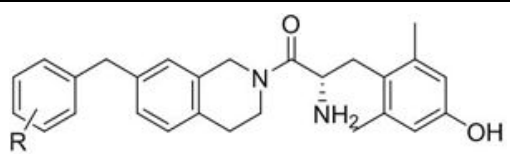

\begin{tabular}{|c|c|c|c|c|c|c|c|c|c|c|}
\hline & & & $\mathbf{K}_{\mathbf{i}}(\mathbf{n M})$ & & & $\mathrm{C}_{50}(\mathrm{nM})$ & & & timulat & \\
\hline & $\mathbf{R}$ & KOR & MOR & DOR & KOR & MOR & DOR & KOR & MOR & DOR \\
\hline $4 c$ & $\mathrm{H}$ & $3.9(0.8)$ & $2.7(0.8)$ & $6.1(2.1)$ & $33(6)$ & - & - & $85(8)$ & dns & dns \\
\hline $10 \mathrm{a}$ & $\mathrm{p}-\mathrm{Me}$ & $233(41)$ & $114(22)$ & $6.0(1.2)$ & - & $158(49)$ & - & dns & $23(3)$ & dns \\
\hline $10 \mathrm{~b}$ & $\mathrm{p}-\mathrm{NO} 2$ & $22(4)$ & $2.6(0.5)$ & $2.9(0.3)$ & $424(84)$ & - & - & $33(8)$ & dns & dns \\
\hline $10 \mathrm{c}$ & $\mathrm{p}-\mathrm{NH} 2$ & $91(7)$ & $47(10)$ & $3.1(0.4)$ & - & - & - & dns & $\mathrm{dns}$ & dns \\
\hline $10 d$ & $\mathrm{~m}-\mathrm{Me}$ & $2.7(0.3)$ & $3.1(0.6)$ & $3.0(0.8)$ & $80(25)$ & $42(13)$ & - & $83(5)$ & $30(2)$ & dns \\
\hline $10 \mathrm{e}$ & $\mathrm{m}-\mathrm{NO} 2$ & $2.5(0.5)$ & $3.1(0.8)$ & $2.5(0.7)$ & $97(30)$ & - & - & $76(6)$ & dns & dns \\
\hline $10 f$ & $\mathrm{~m}-\mathrm{NH} 2$ & $28(4)$ & $9.7(2.4)$ & $5.5(0.9)$ & $405(65)$ & - & - & $24(3)$ & dns & dns \\
\hline $10 \mathrm{~g}$ & $\mathrm{o}-\mathrm{Me}$ & $1.2(0.2)$ & $2.5(0.3)$ & $5.8(1.1)$ & $28(7)$ & $48(16)$ & - & $96(9)$ & $21(4)$ & dns \\
\hline $10 \mathrm{~h}$ & o-NO2 & $2.6(1.0)$ & $10(2)$ & $4.7(1.5)$ & $32(6)$ & - & - & 77 (2) & $\mathrm{dns}$ & dns \\
\hline $10 \mathrm{i}$ & o-NH2 & $25(5)$ & $2.1(0.1)$ & $9.0(2.2)$ & $471(56)$ & $116(40)$ & - & $96(11)$ & $27(4)$ & dns \\
\hline
\end{tabular}

